\title{
THE GENETIC CONTROL OF RIBOSOMAL RNA ACCUMULATION IN FLAX GENOTROPHS
}

\author{
NEASA NI GHOGAIN,* HENRY BYRNE† and JEREMY TIMMIS $\ddagger$ \\ Department of Botany, University College, Belfield, Dublin 4, Ireland
}

Received 17.viii.81

\begin{abstract}
SUMMARY
The relationship between rRNA gene dosage, rRNA synthesis and various phenotypic characters was studied in environmentally induced phenotypically and genetically distinct flax lines. Large (L) and small (S) types had 2210 and 1110 rRNA genes respectively, assessed by rRNA/DNA hybridization. The mean fresh weight of mature $\mathrm{L}$ and $\mathrm{S}$ plants was $165 \mathrm{~g}$ and $98 \mathrm{~g}$, respectively. Root growth rates were linear during the first five days after germination, showing a mean value of $1.35 \mathrm{~cm} /$ day for $\mathrm{L}$ and $0.77 \mathrm{~cm} /$ day for $S$. Accumulation of RNA showed a parallel difference with $2.46 \mu \mathrm{g} /$ day in $\mathrm{L}$ and $1.48 \mu \mathrm{g} /$ day in S. At two-three days after germination the rate of synthesis of RNA (assessed by either $\left({ }^{32} \mathrm{P}\right)$-orthophosphate incorporation or by $\left({ }^{3} \mathrm{H}\right)$-adenosine incorporation and measurement of the specific activity of the ATP pools by the luciferin/luciferase assay) was not significantly different between $L$ and $S$ types. However polyacrylamide gel electrophoretic analysis of the $\left({ }^{32} \mathrm{P}\right)$-rRNA indicated a 25 per cent greater proportion of RNA synthesis devoted to production of pre-rRNA in L compared with S types. In addition there is evidence of more efficient processing of the pre-rRNA in $S$ types but greater stability of the mature rRNAs of $L$ lines. These post-transcriptional controls appear to be mainly responsible for the greater accumulation of rRNA in phenotypically large types. The rRNA gene number changes and corresponding changes in transcription of pre-rRNA appear to be relatively unimportant in regulating the accumulation of rRNA.
\end{abstract}

\section{INTRODUCTION}

HIGHER plants exhibit a wide variation in the number of genes coding for ribosomal RNA (rRNA). The sequence varies in number from about 1000 to about 32,000 copies per nucleus in different species (Ingle et al., 1975). In general there appears to be no correlation between gene dosage and the amount of gene product. Hyacinth, for example, with 16,700 gene copies accumulates a very similar amount of RNA per root cell as artichoke which has only 1580 copies of the gene (Timmis and Ingle, 1975b). Clearly a whole range of efficiency of utilization of rRNA genes exists in higher plants. In addition to these observations, it has been shown using euploid and aneuploid varieties of hyacinth, that whole nucleolus organizing chromosomes may be removed from the complement without causing any decrease in amount of rRNA accumulated per cell (Timmis and Ingle, $1975 b$ ). Similarly, the addition of a nucleolus organizing chromosome using a line trisomic for this chromosome, does not increase rRNA accumulation. These experiments illustrate that large positive and negative distortions of up to 50 per cent in rRNA gene dosage are not reflected in the amount

Present addresses: * The Regional Technical College, Athlone, Co. Westmeath, Ireland; $\uparrow$ Research Laboratories, A. Guinness and Co. Lid., St. James' Gate, Dublin, Ireland; $\ddagger$ To whom reprint requests should be sent. 
of that gene product. The inference is that rRNA genes are redundant in a true sense, at least in root cells. Hyacinth rRNA gene multiplicity is however one of the highest recorded and the ability of this species to tolerate aneuploidy is atypical. It may be that plants with low rRNA redundancies do show quantitative regulation of rRNA accumulation. Such control has been clearly demonstrated in Drosophila (Ritossa et al., 1966; Weinmann, 1972) where rRNA gene numbers are very much lower.

The environmentally induced genetically different lines of flax (Durrant, 1958, 1962a; Joarder et al., 1975) are suitable material to test for the control of rRNA production by specific rRNA gene dosage for a number of reasons. Flax rRNA gene redundancy is very low compared with hyacinth and at the low end of the spectrum observed in plants (Ingle et al., 1975). There are positive correlations reported for flax genotrophs between plant vigour, nucleolar size, nuclear RNA content, and rRNA gene redundancy (Timmis and Ingle, 1973, 1975; Joarder et al., 1975; Frankham, 1977). These correlations suggest that in the flax lines the rate of accumulation of rRNA is a limiting factor for plant growth rate and final yield. There are, however, a number of valid reasons to suspect that the changes in rDNA content are not causal to the process of environmentally induced genetic changes in flax and that the correlations referred to above are fortuitous (Cullis, 1976, 1977, 1979).

In the following we report the results of experiments designed to fully investigate the relationship between phenotype and rRNA gene dosage in six environmentally induced lines of flax differing in various combinations of plant vigour, nuclear DNA content and rRNA gene dosage. Appropriate material is further used to test the hypothesis that phenotypic vigour is controlled by the availability of ribosomes which is in turn subject to the rate of rRNA synthesis and the number of rRNA genes available for transcription.

\section{MATERIAls AND METHODS}

\section{(i) Plant material}

Seeds of induced lines of the flax variety Stormont Cirrus were obtained from Dr A. Durrant. The nomenclature used to designate the environmental history of the lines is that of Joarder et al. (1975). Subscript numbers refer to the number of generations spent in $\mathrm{T}_{2}$ (growth totally outdoors), the "reverting" environment. Where subscript zero is used these lines are the fully induced original large $\left(\mathrm{L}_{0}\right)$ and small $\left(\mathrm{S}_{0}\right)$ genotrophs maintained in $T_{1}$ (at least the first five weeks after germination spent in a heated greenhouse). Seed stocks were maintained in Dublin by growth under $\mathrm{T}_{1}$ conditions. For field experiments, the lines were planted in multipots in late April in a greenhouse, then subsequently transplanted into the field in a randomized block design with eight replicates. Various parameters were measured during growth and fresh weight was obtained at maturity.

\section{(ii) Extraction and fractionation of nucleic acids}

Nucleic acids were prepared as described by Parish and Kirby (1966). Flax DNA, purified on neutral $\mathrm{CsCl}$ gradients, was denatured and fixed to 
Millipore filters (15-20 $\mu \mathrm{g} /$ filter) (Scott and Ingle, 1973). Ribosomal RNA, prepared from rose cells cultured in the presence of $\left({ }^{32} \mathbf{P}\right)$-orthophosphate $\left(150 \mu \mathrm{Ci} / \mathrm{ml}^{-1}\right)$, was fractionated by polyacrylamide gel electrophoresis. Sections of gel containing the large and small subunit rRNAs were located, sliced into $0.2 \mathrm{~mm}$ slices, and the rRNAs eluted in $6 \times \mathrm{SSC}$ (SSC is $0.15 \mathrm{M}$ $\mathrm{NaCl}$ with $0.015 \mathrm{MNa}$-citrate, $p \mathrm{H} 7 \cdot 2$ ) at $50^{\circ} \mathrm{C}$ for $2 \mathrm{~h}$ (Scott and Ingle, 1973). The specific activity of rRNA was between 0.5 and $1.2 \times 10^{6} \mathrm{cpm} \mu \mathrm{g}^{-1}$ in different experiments.

\section{(iii) Hybridization of $r R N A$ to $D N A$}

The DNA filters were incubated with an equimolar mixture of labelled rRNA $\left(5 \mu \mathrm{g}\right.$ of $1.3 \times 10^{6}$ and $2.5 \mu \mathrm{g}$ of $0.7 \times 10^{6}$ dalton rRNAs per ml of hybridization mix) in $6 \times \mathrm{SSC}$ at $70^{\circ} \mathrm{C}$ for $2.5 \mathrm{~h}$. In one experiment to determine the kinetics of hybridization, filters were removed at intervals during hybridization. The filters were washed, treated with RNAase, and the radioactivity retained determined by scintillation counting. Scintillant was removed by chloroform washing, and the DNA present on the filters was determined by hydrolysis at $100^{\circ} \mathrm{C}$ in $1 \mathrm{~N} \mathrm{HCl}$ for $15 \mathrm{~min}$ and then determining the absorbance at $260 \mathrm{~nm}$ of the resulting hydrolysate.

\section{(iv) Measurement of root growth rate}

Surface sterilized seeds were placed on moist paper in petri dishes under sterile conditions and germinated at $25^{\circ} \mathrm{C} \pm 1^{\circ} \mathrm{C}$. The growth rate was monitored by destructive sampling of 3 roots from replicate dishes, at intervals over an eight day period.

\section{(v) Estimation of RNA content}

Roots were grown as above and ground in cold $0.5 \mathrm{M}$ perchloric acid (PCA) by a mechanical teflon homogenizer designed to fit $15 \mathrm{ml}$ corex tubes. After precipitation of macromolecules the samples were filtered on glass fibre discs (Whatman GFC) and washed twice with $0.5 \mathrm{M}$ PCA and three times with ethanol: ether: chloroform $(2: 2: 1)$. The filters and residue were hydrolysed in $0.3 \mathrm{M} \mathrm{KOH}$ for $16 \mathrm{hr}$ at $25^{\circ} \mathrm{C}$. After acid precipitation and removal of DNA, the $\mathrm{OD}_{260}$ of the hydrolysate was measured. The amount of total RNA was calculated per root section assuming a tetranucleotide structure for RNA $\left(\mathrm{OD}_{260} \times 31 \cdot 7\right)$ (Timmis and Ingle, $\left.1975 b\right)$. In one experiment this method was combined with a $\left({ }^{32} \mathrm{P}\right)$-orthophosphate label of the roots for 1 and $24 \mathrm{hr}$ to determine the specific activity of the RNA accumulated in the different lines.

\section{(vi) Measurement of the rate of RNA synthesis}

Roots were grown under sterile conditions as described above and great care was taken to ensure that no differences in growth were caused by microclimate. Seeds of the $\mathrm{L}$ and $\mathrm{S}$ types were grown for three days in parallel lines in pie dishes at $25^{\circ} \mathrm{C}$. Samples ( 15 root tips) were taken from neighbouring seedlings at suitable times after addition of $\left({ }^{3} \mathrm{H}\right)$-adenosine $(20 \mu \mathrm{Ci} / \mathrm{ml})$. The root tips were washed in cold water containing $1 \mathrm{mM}$ 
unlabelled adenosine, blotted dry and stored in liquid nitrogen. The tissue was homogenized in $2 \mathrm{ml}$ of ice cold $0.5 \mathrm{M}$ PCA containing $1 \mathrm{mM}$ unlabelled adenosine. A $20 \mu$ l aliquot of the homogenate was counted on a GFC filter to assess uptake of adenosine. After precipitation on ice for $\mathbf{5 0}$ minutes the precipitate was collected on GFC filters and washed with a further $2 \mathrm{ml}$ of $0.5 \mathrm{M}$ PCA. The precipitate was processed as described above for the estimation of RNA and the specific activity of the RNA calculated by scintillation counting of $1 \mathrm{ml}$ aqueous samples in a Triton/toluene based scintillant.

The filtrate and a standard ATP solution were mixed with well washed activated charcoal and agitated on ice for $10 \mathrm{~min}$. The charcoal with bound ATP was recovered by filtration on GFC as above and washed ten times with $5 \mathrm{ml}$ of ice-cold water. The filters were then incubated for $30 \mathrm{~min}$ at $37^{\circ} \mathrm{C}$ in $1 \mathrm{ml}$ of $0.1 \mathrm{M} \mathrm{NH}_{4} \mathrm{OH}$ in 50 per cent ethanol. The samples were air dried, redissolved in 5-10 $\mu$ l of $0.1 \mathrm{~N} \mathrm{NaOH}$ and co-chromatographed on cellulose plates with standard ATP preparations. The plates were developed for 4-6 hr in isobutyric acid:water:concentrated $\mathrm{NH}_{4} \mathrm{OH}$ $(66: 33: 1)$. The slow half of the ATP spot was eluted for five min in $1 \mathrm{ml}$

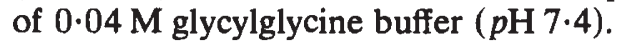

The amount of ATP was estimated by the calibrated luciferin/luciferase reaction (Humphreys, 1973). Samples were measured within the linear portion of the reaction curve $\left(1-5 \times 10^{-12}\right.$ moles of ATP). The specific activity of the ATP was calculated and plotted over the course of the experiment. From these figures the rate of incorporation of ATP into RNA was calculated.

\section{(vii) ${ }^{32} P$-orthophosphate labelling and polyacrylamide gel fractionation of $R N A$}

Seedlings were prepared as before for three days and incubated in $0.5 \mu \mathrm{M}$ phosphate buffer ( $p \mathrm{H} 6.9)$ containing $80 \mu \mathrm{Ci} / \mathrm{ml}\left({ }^{32} \mathrm{P}\right)$-orthophosphate for $1 \mathrm{hr}$ (Jackson and Ingle, 1973). Some seedlings were removed, washed in $5 \mu \mathrm{m}$ phosphate buffer and allowed to grow on this medium for a further $24 \mathrm{hr}$. After the $1 \mathrm{hr}$ (pulse) and $24 \mathrm{hr}$ (chase) treatments nucleic acids were extracted in detergent medium (Parish and Kirby, 1966) and fractionated on 2.4 per cent polyacrylamide gels (Jackson and Ingle, 1973). The gels were scanned at $265 \mathrm{~nm}$, sliced into $1 \mathrm{~mm}$ slices, dried onto cellulose and radioactivity monitored by scintillation counting. The radioactivity histograms were accurately matched with the optical absorbance profiles by particulate ink marks in the gel.

Discontinuous $(2 \cdot 4 / 7.5$ per cent) polyacrylamide gels were used to determine the contribution of rRNA to total RNA in the various flax lines (Timmis and Ingle, 1975).

\section{Results AND Discussion}

\section{(i) Characterization of the flax genotrophs}

In view of the complexities and obscurities associated with maintaining fully characterized flax genotrophs (Durrant, 1971), the lines used in the following experiments on RNA metabolism were concomitantly subjected 
to a fully replicated field experiment designed to determine their phenotypes. The mean data in table 1 show plant weight, height, number of side branches, total shoot length and flowering time for six flax genotrophs. The variation in plant size is comparable with that reported previously (Durrant 1971). Two of the types $\left(\mathrm{L}_{0}\right.$ and $\mathrm{L}_{3}$ ) are generally similar to each other and significantly more vigorous than the other four types $\left(S_{0}, S_{3}, L_{6}\right.$ and $\left.S_{6}\right)$. The reversion of $L_{6}$ from large to small phenotype has been noted by Durrant (personal communication).

Roots are the most convenient material in which to study RNA metabolism in plants, as they incorporate RNA precursor molecules well and represent a comparable and relatively homogeneous tissue type. In addition the root tip cells are probably some of the most active of the plant and are therefore likely to show maximum rates of net accumulation of rRNA. It is clear that only cells which are utilizing their rRNA genes at maximal rates are likely to be influenced by variations in rRNA gene redundancy. To test whether the variations in shoot growth characteristics (table 1) are

TABLE 1

Mean plant fresh weights, plant heights, side branch numbers, total shoot lengths, and flowering times of six genotrophs of flax

$\begin{array}{cccccc}\text { Genotroph } & \begin{array}{c}\text { Fresh weight } \\ (\mathrm{g})\end{array} & \begin{array}{c}\text { Plant height } \\ (\mathrm{cm})\end{array} & \begin{array}{c}\text { Side branch } \\ \text { number }\end{array} & \begin{array}{c}\text { Total shoot } \\ \text { length } \\ (\mathrm{cm})\end{array} & \begin{array}{c}\text { Flowering } \\ \text { time* } \\ (\text { days })\end{array} \\ \mathrm{L}_{0} & 169 & 24 \cdot 0 & 8 \cdot 2 & 109.4 & 18.7 \\ \mathrm{~S}_{0} & 96 & 19.8 & 6.8 & 51.8 & 18.8 \\ \mathrm{~L}_{3} & 170 & 23.8 & 8.1 & 97.4 & 19.9 \\ \mathrm{~S}_{3} & 100 & 20.5 & 6.5 & 60.5 & 18.1 \\ \mathrm{~L}_{6} & 80 & 17.2 & 5 \cdot 2 & 39.0 & 21.8 \\ \mathrm{~S}_{6} & 80 & 16.5 & 5.2 & 34.9 & 21.3 \\ \text { Probability } & <0.001 & <0.001 & <0.001 & <0.001 & <0.001 \\ \mathrm{D}_{5 \%} & 47 & 2.2 & 1.8 & 22.4 & 3.1 \\ \mathrm{D}_{1 \%} & 58 & 2.7 & 2.2 & 27.4 & 3.8\end{array}$

Each value is the mean of eight replicates with four individual plant measurements in each replicate.

* Number of days to flowering after transplantation out-of-doors.

$\mathrm{D}=$ Least significant difference.

also present in roots, the length of roots of six lines was determined in two experiments between 48 and 168 hours after germination. The growth of all the lines was found to be linear from $48 \mathrm{hr}$ up to $120 \mathrm{hr}$ and the four phenotypically small types showed a significant $(P<0.001) 40$ per cent reduction in rate of root growth compared with the large types (fig. 1). A second experiment showed a significant $(P<0.05)$ overall increase in the growth rate of both $L$ and $S$ phenotypes, although similar percentage differences $(P<0.001)$ were revealed between the contrasting phenotypes. These findings and observations from subsequent experiments discussed later stress the susceptibility of flax root growth to microclimatic variations. The fluctuations may possibly be attributed to variable carry-over of sterilization agents through extensive washes or to seedling ethylene production and variation in aeration between petri dishes. 


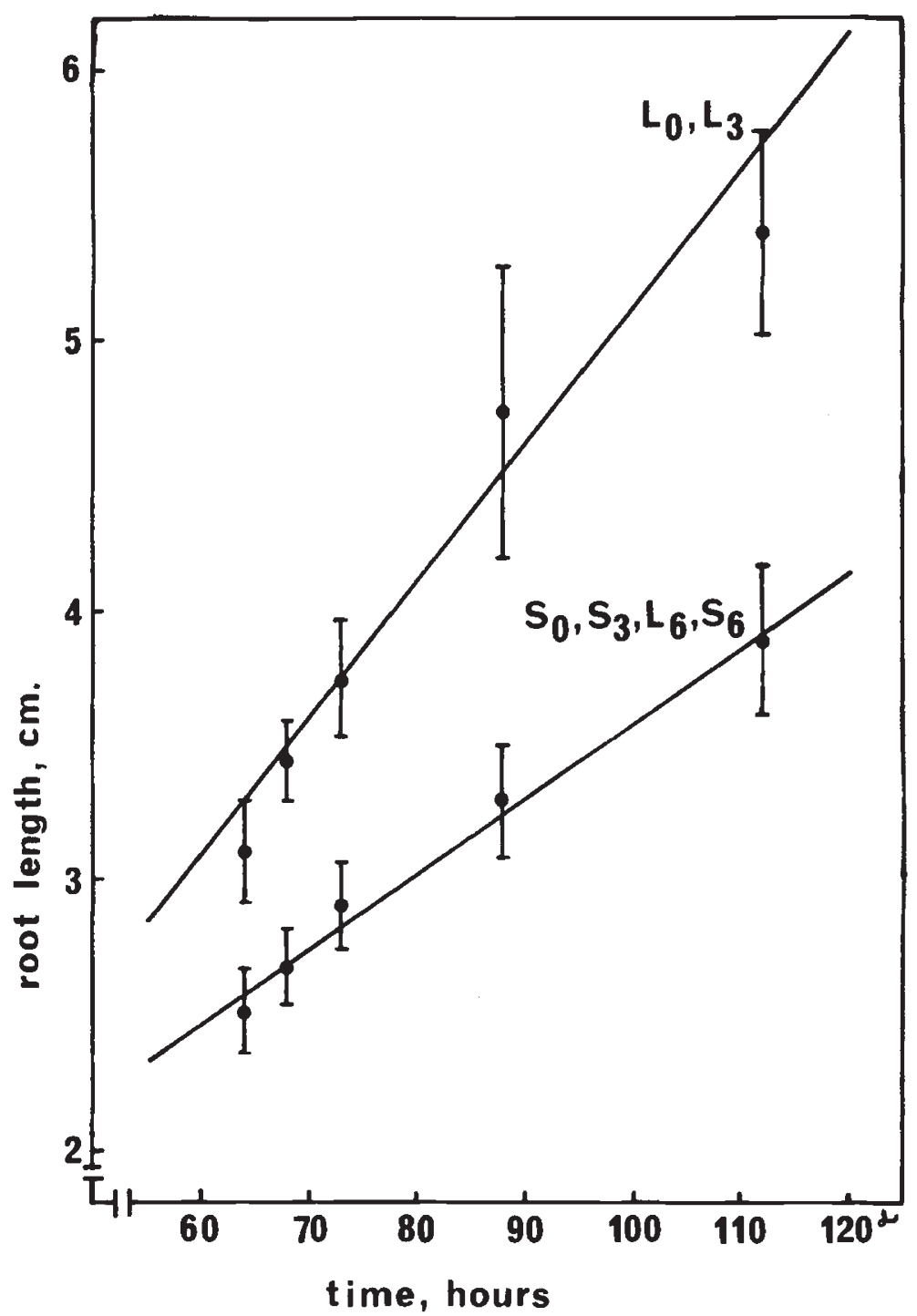

FIG. 1.-Root growth rates in six flax genotrophs. Seedlings were grown in replicate petri dishes and sampled destructively at the stated times after planting. Each point is the mean of three replicates with four plants measured in each replicate. Statistical analysis showed that the growth rate of phenotypically large types $\mathrm{L}_{0}$ and $\mathrm{L}_{3}$ differs significantly $(P<0.001)$ from the small types $\mathrm{S}_{0}, \mathrm{~S}_{3}, \mathrm{~S}_{6}$ and $\mathrm{L}_{6}$, with no significant variation within phenotypes. The regression coefficients are $0.0477 \pm 0.0058$ for large phenotypes and $0.0278 \pm 0.0017$ for small phenotypes. Both regression coefficients are highly significant $(P<0.01$ and $P<0.001$ respectively).

\section{(ii) Ribosomal RNA gene numbers}

The number of rRNA genes in large and small flax types has been determined previously and shown to be greater in $\mathrm{L}$ than $\mathrm{S}$ types. The existence of a causal relationship has been suggested (Timmis and Ingle, 
1973, 1975a; Frankham, 1977) but is the subject of some controversy (Cullis, 1976, 1977) and evidence for such a relationship is circumstantial. Further, the gene numbers published, while indicating very similar patterns, show considerable variations in absolute estimation of rRNA sequence complementarity (cf. Cullis, 1976 and 1979). These variations may either be of technical origin or they may be real differences resulting from further subtle environmentally controlled fluctuations.

In view of the above observations the rRNA gene numbers in the plant material were determined in duplicate experiments using saturation hybridization to rRNA of very high specific activity (table 2 ). The results

TABLE 2

Percentage of DNA complementary to $1.3 \times 10^{6}+0.7 \times 10^{6}$ molecular weight rRNA, and the calculated number of rRNA genes per $2 C$ nucleus in six flax genotrophs

\begin{tabular}{|c|c|c|c|c|}
\hline Genotroph & $\begin{array}{c}\text { Experiment }(\mathrm{i}) \\
\% \text { hybridization } \pm \text { Sd } \\
\text { No. of } r \text { RNA } \\
\text { genes } \pm \text { Sd }\end{array}$ & $\begin{array}{c}\text { Experiment (ii) } \\
\% \text { hybridization } \pm \text { Sd } \\
\text { No. of } r \text { RNA } \\
\text { genes } \pm \text { Sd }\end{array}$ & $\begin{array}{l}{ }^{*} \mathrm{DNA} / 2 \mathrm{C} \\
\text { nucleus } \\
\times 10^{12} \mathrm{~g}\end{array}$ & $\begin{array}{l}\text { Mean number } \\
\text { rRNA genes } / 2 \mathrm{C} \\
\text { nucleus }\end{array}$ \\
\hline $\mathrm{L}_{0}$ & $\begin{array}{c}0.465 \pm 0.036 \\
2158 \pm 159\end{array}$ & $\begin{array}{c}0.443 \pm 0.023 \\
2052 \pm 106\end{array}$ & 1.54 & 2118 \\
\hline$S_{0}$ & $\begin{array}{c}0.317 \pm 0 \cdot 028 \\
1251 \pm 110\end{array}$ & $\begin{array}{c}0.364 \pm 0 \cdot 021 \\
1434 \pm 83\end{array}$ & $1 \cdot 31$ & 1320 \\
\hline $\mathrm{L}_{3}$ & $\begin{aligned} 0.543 & \pm 0.015 \\
2322 & \pm 65\end{aligned}$ & $\begin{array}{c}0.532 \pm 0.031 \\
2274 \pm 133\end{array}$ & 1.42 & 2304 \\
\hline$S_{3}$ & $\begin{aligned} 0 \cdot 205 & \pm 0 \cdot 007 \\
878 & \pm 32\end{aligned}$ & $\begin{aligned} 0 \cdot 219 & \pm 0 \cdot 016 \\
938 & \pm 69\end{aligned}$ & 1.42 & 900 \\
\hline $\mathrm{L}_{6}$ & $\begin{array}{c}0 \cdot 306 \pm 0 \cdot 040 \\
1236 \pm 161\end{array}$ & $\begin{aligned} 0 \cdot 315 & \pm 0 \cdot 007 \\
1274 & \pm 30\end{aligned}$ & 1.34 & 1250 \\
\hline$S_{6}$ & $\begin{array}{c}0 \cdot 297 \pm 0 \cdot 016 \\
1190 \pm 64\end{array}$ & $\begin{aligned} 0 \cdot 309 & \pm 0 \cdot 012 \\
1237 & \pm 48\end{aligned}$ & $1 \cdot 33$ & 1208 \\
\hline
\end{tabular}

Experiment (i): Five filters for each genotroph, hybridized for 3 hours at $70^{\circ} \mathrm{C}$ in $6 \times \mathrm{SSC}$. $6 \times$ SSC.

Experiment (ii): Three filters for each genotroph, hybridized for 4.5 hours at $70^{\circ} \mathrm{C}$ in

* From Cullis (1976) and Timmis and Ingle (1975a).

are comparable with previous reports although $\mathrm{S}_{3}$ appears to be particularly low in redundancy. The absolute percentage of complementarity to the sequence is similar to the early publication of Cullis (1976) but lower than those of Cullis (1979) and Timmis and Ingle $(1973,1975 a)$. The possibility of real differences caused by growth conditions therefore remains. In order to check the genetical stability of the sequence and the within-line variation, rRNA gene numbers were determined in individual plants of $\mathrm{L}_{0}, \mathrm{~S}_{0}$ and their reciprocal crosses (table 3 ). These results indicate between-plant variation in rDNA content (up to 45 per cent) with no evidence of generation of increased variation in the $F_{1}$, and with mean equilinear inheritance of rRNA genes (cf. Cullis, 1979). The increased variance in $F_{1}$ described by Cullis (1979) and not found in the results of table 3 may be explained by genetic instability arising in heterozygotes in some environments and not in others. This is known to occur in plant weight (Durrant, 1962b) in the $F_{1}$ crosses between $L$ and $S$ genotrophs. The presence of significant 
TABLE 3

Ribosomal RNA gene numbers in individual plants of $L_{0}$ and $S_{0}$ flax genotrophs, and their reciprocal crosses. Each value obtained from 4 replicate filters. Hybridization conditions as for Table 2

\begin{tabular}{|c|c|c|}
\hline $\begin{array}{c}\text { Genotroph } \\
\text { (2C nuclear DNA value) }\end{array}$ & $\begin{array}{l}\text { rRNA genes/ } \\
2 \mathrm{C} \text { nucleus } \\
\pm S d\end{array}$ & $\begin{array}{c}\text { Mean rRNA } \\
\text { gene number } \\
\pm \text { Sd }\end{array}$ \\
\hline $\begin{array}{c}\mathrm{L}_{0} \\
(1 \cdot 540)\end{array}$ & $\begin{array}{l}2021 \pm 239 \\
2937 \pm 217 \\
2524 \pm 457 \\
2509 \pm 169 \\
2822 \pm 368 \\
2528 \pm 356\end{array}$ & $2557 \pm 318$ \\
\hline $\begin{array}{c}S_{0} \\
(1 \cdot 310)\end{array}$ & $\begin{array}{l}1495 \pm 218 \\
1284 \pm 116 \\
1393 \pm 176 \\
1462 \pm 103 \\
1725 \pm 226 \\
1505 \pm 84\end{array}$ & $1477 \pm 146$ \\
\hline $\begin{array}{l}\mathrm{L}_{0} \times \mathrm{S}_{0} \\
(1.425)\end{array}$ & $\begin{array}{l}1987 \pm 219 \\
1647 \pm 181 \\
2120 \pm 162 \\
1864 \pm 232 \\
1988 \pm 85 \\
1947 \pm 142\end{array}$ & $1926 \pm 160$ \\
\hline $\begin{array}{l}S_{0} \times L_{0} \\
(1.425)\end{array}$ & $\begin{array}{l}2204 \pm 177 \\
2167 \pm 243 \\
1621 \pm 173 \\
2137 \pm 90\end{array}$ & $2032 \pm 275$ \\
\hline
\end{tabular}

variation between plants of the same genotroph indicates the need for large samples of roots in the analyses of rRNA synthesis. A minimum of 15 individuals was used in each sample in later labelling experiments.

\section{(iii) The relationship between $r R N A$ gene number and phenotype}

Using the regression coefficient $(b)$ (Frankham, 1977) to determine significance of association between rRNA gene number and various phenotypic characters we find that gene number is significantly associated with root growth rate $(b=1159.0 \pm 132.2, P<0.001)$, plant weight $(b=$ $12 \cdot 14 \pm 2 \cdot 61, P<0.01)$ and total shoot length $(b=15 \cdot 39 \pm 4 \cdot 74, P<0.05)$; other associations except that with flowering time approach significance. These findings constitute further circumstantial evidence for control of phenotypic vigour in flax by quantitative variation in the rRNA gene sequence.

\section{(iv) Accumulation of rRNA per day in roots}

Table 4 shows triplicate data obtained from total RNA estimations and lengths of whole flax roots (excluding the hypocotyl) on the third and fourth days after imbibition in four selected genotrophs. The two phenotypically large types $\left(\mathrm{L}_{0}\right.$ and $\left.\mathrm{L}_{3}\right)$ produce significantly more RNA during the period than the small types $\left(S_{0}\right.$ and $\left.S_{3}\right)$. The difference in mean amount of RNA 
TABLE 4

Accumulation of RNA and growth in length of flax roots. Seedlings of 4 selected lines were sown in triplicate dishes in two experiments and total RNA and length estimated after 3 and after 4 days. These values were used to calculate amount of RNA accumulated and length grown per root per day. Large phenotypes $L_{0}$ and $L_{3}$ accumulate significantly more $R$ NA per day than small phenotypes $S_{0}$ and $S_{3}(P<0.001)$

\begin{tabular}{|c|c|c|c|c|}
\hline \multirow[b]{2}{*}{ Genotroph } & \multicolumn{2}{|c|}{ Experiment 1} & \multicolumn{2}{|c|}{ Experiment 2} \\
\hline & $\begin{array}{l}\text { RNA accumulation } \\
(\mu \mathrm{g} / \text { root } / \text { day })\end{array}$ & $\begin{array}{l}\text { Length } \\
\text { (cm/day) }\end{array}$ & $\begin{array}{l}\text { RNA accumulation } \\
(\mu \mathrm{g} / \mathrm{root} / \text { day })\end{array}$ & $\begin{array}{c}\text { Length } \\
\text { (cm/day) }\end{array}$ \\
\hline $\mathrm{L}_{0}$ & $\begin{array}{l}3.45 \\
3.82 \\
3.64\end{array}$ & $\begin{array}{l}2.71 \\
2.96 \\
2.23\end{array}$ & $\begin{array}{l}2.42 \\
2.69 \\
3.09\end{array}$ & $\begin{array}{l}1.06 \\
0.97 \\
1.43\end{array}$ \\
\hline Mean & $\overline{3.64}$ & $\overline{2 \cdot 63}$ & $\overline{2.73}$ & $\overline{1.15}$ \\
\hline $\mathbf{S}_{0}$ & $\begin{array}{l}1.38 \\
1.38 \\
1.64\end{array}$ & $\begin{array}{l}1.27 \\
1.13 \\
1.67\end{array}$ & $\begin{array}{l}1.51 \\
0.93 \\
0.42\end{array}$ & $\begin{array}{l}1.01 \\
0.75 \\
0.29\end{array}$ \\
\hline Mean & $\overline{1.47}$ & $\overline{1 \cdot 36}$ & $\overline{0.95}$ & $\overline{0.68}$ \\
\hline $\mathrm{L}_{3}$ & $\begin{array}{l}3.79 \\
3.36 \\
3.19\end{array}$ & $\begin{array}{l}2 \cdot 30 \\
3 \cdot 10 \\
3.27\end{array}$ & $\begin{array}{l}1.98 \\
1.55 \\
1.90\end{array}$ & $\begin{array}{l}1.51 \\
0.74 \\
1.12\end{array}$ \\
\hline Mean & $\overline{3.45}$ & $\overline{2 \cdot 89}$ & $\overline{1.81}$ & $\overline{1 \cdot 12}$ \\
\hline$S_{3}$ & $\begin{array}{l}2 \cdot 13 \\
2 \cdot 49 \\
2 \cdot 39\end{array}$ & $\begin{array}{l}1.36 \\
0.89 \\
1.14\end{array}$ & $\begin{array}{l}0.54 \\
1.48 \\
1.50\end{array}$ & $\begin{array}{l}0.28 \\
1.13 \\
0.50\end{array}$ \\
\hline Mean & $\overline{2 \cdot 34}$ & $\overline{1 \cdot 13}$ & $\overline{1 \cdot 17}$ & $\overline{0.64}$ \\
\hline $\mathrm{D}_{5 \%}$ & 0.40 & 0.67 & 0.82 & 0.71 \\
\hline$D_{1 \%}$ & 0.57 & 0.97 & $1 \cdot 17$ & 1.02 \\
\hline
\end{tabular}

accumulated ( 96 per cent) closely parallels the difference in mean rRNA gene redundancy ( 99 per cent) so that the amount of RNA accumulated per gene is relatively constant. This finding further suggests a quantitative genetic control of RNA synthesis. A second similar experiment yielded substantially confirmatory results (table 4) but showed significant differences between absolute RNA amounts and root growth. Technical or minor environmental disturbances of the type previously mentioned are held to be responsible for this replicate variation. In both sets of data, RNA is accumulated faster in $\mathrm{L}$ than in $\mathrm{S}$ types. To determine whether analysis of total RNA by alkaline hydrolysis reflects what is occurring in $25 \mathrm{~S}$ and $18 \mathrm{~S}$ rRNAs, discontinuous $2 \cdot 4 / 7 \cdot 5$ per cent polyacrylamide gels were analysed for the contribution of $4 S$ and 5S RNAs. The percentage of the major rRNAs, estimated by their relative absorbance at $265 \mathrm{~nm}$, was found to be very constant at $81.4 \pm 1.5$ per cent in the four lines analysed.

\section{(v) Rate of RNA synthesis in root tips}

Whole plant tissues are not ideal for comparative studies in RNA metabolism. Even a restricted tissue such as root is highly heterogeneous and there are obvious dangers in tissue selection generating spurious results. Wide variations in the kinetics of $\left({ }^{3} \mathrm{H}\right)$-adenosine uptake, ATP synthesis 
and incorporation into RNA were only removed by utilizing the most stringent methods of ensuring identical environments. The types selected for labelling experiments were grown together in large dishes and sampled as contiguous groups utilizing the whole area of the dish for each sample. In the RNA synthesis experiments which follow, the root lengths were sampled and determined to show the expected difference in root length at the time of each experiment.

The root tip ( $0-2 \mathrm{~mm})$ was selected for comparison as the most reliably homogeneous and metabolically active tissue. L and S seedlings had a constant percentage (38 per cent \pm 3 per cent) of total RNA was within this region at 3 days after planting. Roots of $L_{3}$ and $S_{3}$ types were grown together in a single dish for three days and samples of 15 roots handled as described in Material and Methods at suitable intervals up to 180 minutes after labelling with ${ }^{3} \mathrm{H}$-adenosine. Labelled adenosine uptake, specific activity of ATP pools and specific activity of total RNA were measured at each time. From these data the rate of incorporation of ATP into RNA was calculated. Fig. 2 shows the results of duplicate experiments with $\mathrm{L}_{3}$ and $S_{3}$ lines. There are no indications of any significant variation in the rate of RNA synthesis between the two genotrophs, no difference in ATP pool size and no difference in uptake of adenosine.

\section{(vi) Incorporation of $\left({ }^{32} P\right)$-orthophosphate into RNA and analysis by polyacrylamide gel electrophoresis}

There appears to be conflict in the results described above which show, on the one hand, that more RNA is accumulated per day in the large genotrophs in a pattern which correlated with rDNA amount and, on the other hand, that no difference in the rate of RNA synthesis can be detected. Growth in a plant root is extremely complex however, as are the events which lead to the accumulation of stable rRNA. A number of factors require consideration:

(1) The root tip, while containing highly active dividing cells, may not be representative of the whole root in its RNA synthesis.

(2) The $\left({ }^{3} \mathrm{H}\right)$-adenosine incorporation method is not able to distinguish between different populations of RNA. After a short labelling period no more than 50 per cent of the counts incorporated will be into rRNA and its precursors (Jackson and Ingle, 1973). This means that rRNA synthesis measurements are heavily confused by incorporation into polydisperse RNA, 4S RNA and 5S RNA, the effects of which could only be removed by recourse to inhibitors such as $\alpha$-amanitin.

As an alternative to using inhibitors, the effects of which are little documented in plants, we have studied incorporation of $\left({ }^{32} \mathrm{P}\right)$-orthophosphate. Phosphates have small pools in most tissues and the labelled RNAs may be fractionated on polyacrylamide gels to separate mature $25 \mathrm{~S}$ and $18 \mathrm{~S}$ rRNA from other RNA populations and also from their precursor molecules which are the rapidly labelled, direct transcription products of the rRNA genes (Jackson and Ingle, 1973). Duplicate gels were run of equal loadings of total nucleic acids from the four lines $\mathrm{L}_{0}, \mathrm{~S}_{0}, \mathrm{~L}_{3}$ and $\mathrm{S}_{3}$ after pulse labelling seedlings with $\left({ }^{32} \mathrm{P}\right)$-orthophosphate for $1 \mathrm{hr}$. A second set of gels was prepared after removal of the label and incubation of the seedlings for a further $24 \mathrm{hr}$ in excess unlabelled phosphate. 


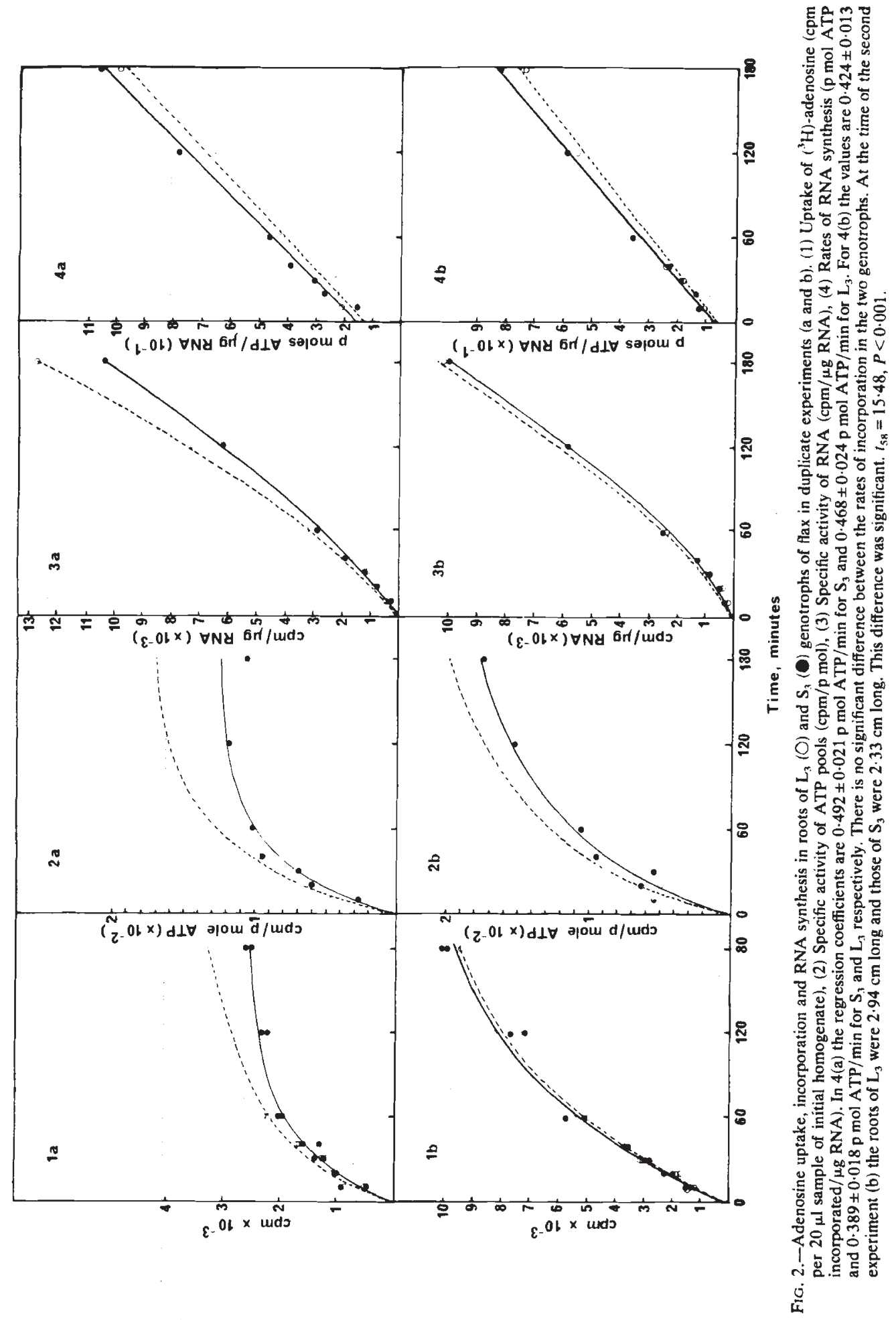


Radioactivity profiles of the sliced gels, partitioned into various nucleic acid fractions, are shown in table 5(a) as radioactive counts per minutes per root section. The results indicate clearly that rRNA gene number does not have a simple quantitative control over either transcription of pre-rRNA or accumulation of mature rRNA assessed by net incorporation of ${ }^{32} \mathrm{P}$ orthophosphate. Indeed the reverse is the case. The two small types incorporate more radioactivity per root into pre-rRNA than the large. However the small phenotypes also incorporate more ${ }^{32} \mathrm{P}$ into all RNA fractions and into DNA, suggesting better uptake systems or a larger meristematic region. In fact the percentage of the total RNA counts incorporated per root into pre-rRNA is greater in $L_{0}$ and $L_{3}$ than in $S_{0}$ and $S_{3}$ (table $5(b)$ ) indicating proportionally greater transcription of rRNA genes. The pulse/chase experiments also suggest that post transcriptional controls may be more important in rRNA metabolism than transcription. The efficiency of processing the pre-rRNA into mature rRNA is clearly, and surprisingly, less in large types than small ones (table 5(b)). The L mature rRNA however appears to be considerably more stable than that of $S$ as more counts survive the chase period. This is demonstrated by the consistently lower

TABLE 5(a)

Radioactivity incorporated by flax genotrophs after pulse/chase incubation in $\left({ }^{32} \mathrm{P}\right)$-orthophosphate. Seedlings of 4 flax genotrophs were incubated in $\left({ }^{32} \mathrm{P}\right)$-orthophosphate $(80 \mu \mathrm{Ci} / \mathrm{ml})$ for $1 \mathrm{hr}$ (pulse) followed by a further $24 \mathrm{hr}$ period in excess non-radioactive phosphate (chase). Nucleic acids were fractionated on 2.4 per cent polyacrylamide gels and counts per minute in the various nucleic acid fractions determined by scintillation counting. Molecular weights are nominal values. Superscript numbers refer to ratios in Table 5(b).

\begin{tabular}{|c|c|c|c|c|c|c|c|c|}
\hline \multirow[b]{2}{*}{ Genotroph } & \multirow[b]{2}{*}{ DNA } & \multirow{2}{*}{$\begin{array}{c}2.5 \times 10^{6} \\
\text { pre- } \\
\text { rRNA }^{1}\end{array}$} & \multicolumn{2}{|c|}{ Pulse } & \multirow[b]{2}{*}{$\begin{array}{l}\text { Polydisperse } \\
\text { RNA }^{3}\end{array}$} & \multicolumn{3}{|c|}{ Chase } \\
\hline & & & $\begin{array}{r}1 \cdot 3+0 \\
\mathrm{rR}\end{array}$ & $\begin{array}{l}7 \times 10^{6} \\
A^{2}\end{array}$ & & $\begin{array}{r}1 \cdot 3+0 \\
\text { IR! }\end{array}$ & $\begin{array}{l}.7 \times 10^{6} \\
N^{4}\end{array}$ & $\begin{array}{l}\text { Polydisperse } \\
\text { RNA }^{5}\end{array}$ \\
\hline $\mathrm{L}_{0}$ & $\begin{array}{l}247 \\
248\end{array}$ & $\begin{array}{l}482 \\
616\end{array}$ & $\begin{array}{l}3624 \\
4390\end{array}$ & $\begin{array}{l}1599 \\
2107\end{array}$ & $\begin{array}{l}9004 \\
7272\end{array}$ & $\begin{array}{l}30,821 \\
33,024\end{array}$ & $\begin{array}{l}15,531 \\
15,530\end{array}$ & $\begin{array}{l}16,613 \\
20,367\end{array}$ \\
\hline$S_{0}$ & $\begin{array}{l}398 \\
397\end{array}$ & $\begin{array}{l}455 \\
765\end{array}$ & $\begin{array}{l}6692 \\
7849\end{array}$ & $\begin{array}{l}3626 \\
3700\end{array}$ & $\begin{array}{l}13,935 \\
10,805\end{array}$ & $\begin{array}{l}46,351 \\
28,508\end{array}$ & $\begin{array}{l}23,440 \\
12,862\end{array}$ & $\begin{array}{l}18,739 \\
18,711\end{array}$ \\
\hline $\mathrm{L}_{3}$ & $\begin{array}{l}238 \\
254\end{array}$ & $\begin{array}{l}553 \\
438\end{array}$ & $\begin{array}{l}2832 \\
4005\end{array}$ & $\begin{array}{l}1699 \\
2071\end{array}$ & $\begin{array}{l}7232 \\
7548\end{array}$ & $\begin{array}{l}31,938 \\
37,396\end{array}$ & $\begin{array}{l}15,925 \\
18,189\end{array}$ & $\begin{array}{l}17,019 \\
21,307\end{array}$ \\
\hline $\mathrm{S}_{3}$ & $\begin{array}{l}339 \\
278\end{array}$ & $\begin{array}{l}624 \\
664\end{array}$ & $\begin{array}{l}6152 \\
5574\end{array}$ & $\begin{array}{l}3151 \\
2596\end{array}$ & $\begin{array}{l}11,304 \\
10,308\end{array}$ & $\begin{array}{l}33,288 \\
43,876\end{array}$ & $\begin{array}{l}15,731 \\
22,041\end{array}$ & $\begin{array}{l}16,334 \\
18,252\end{array}$ \\
\hline
\end{tabular}

TABLE 5(b)

Mean ratios of RNA species resolved by electrophoresis used for assessing the relative transcription, processing and stability of $R$ NAs in flax genotrophs. The numbers explaining the derivations of the ratios refer to the superscript numbers heading the columns of Table S(a)

$\begin{array}{ccccc}\text { \% counts in } & \begin{array}{c}\text { Efficiency of } \\ \text { processing } \\ \text { pre-rRNA }\end{array} & \begin{array}{c}\text { pre-rRNA to rRNA } \\ \text { prenservation } \\ \text { Genotroph }\end{array} & \begin{array}{c}\text { Conservation of } \\ \text { of rRA }\end{array} & \begin{array}{c}\text { polydisperse } \\ \text { RNA }\end{array} \\ \mathrm{L}_{0} & 3+2+3) \times 100 & (2 \div 1) & (4 \div 2) & (5 \div 3) \\ \mathrm{S}_{0} & 2.71 & 10.67 & 8.09 & 2.27 \\ \mathrm{~L}_{3} & 3.76 & 17.92 & 5.08 & 1.51 \\ \mathrm{~S}_{3} & 3.19 & 10.69 & 9.75 & 2.59 \\ & & 13.57 & 6.58 & 1.60\end{array}$


conservation ratios (table 5(b)) in S than L types. Prolonged growth with these characteristics would lead to the overall greater and faster accumulation of mature rRNA in large genotrophs. It is interesting to note in passing that the polydisperse RNA is also more stable in these experiments in $L$ than $\mathrm{S}$ lines, indicating that the half life of most RNA molecules may be greater. These differential stabilities may affect phenotype by regulating translation of mRNA into polypeptides.

The chase experiments reported here, in common with others (Timmis and Ingle, 1975) are very inefficient; radioactivity increases up to ten fold during the chase even though the external label is removed. This factor complicates the interpretation of results as differential uptakes and replacement of pools may be interpreted erroneously. To check that our assumptions regarding differential stability of mature ribosomal RNA are valid, a further set of roots was continuously labelled with $\left({ }^{32} \mathrm{P}\right)$-orthophosphate without the complication of the chase effect or gel analysis of the products. In this case RNA amount was estimated by mild alkaline hydrolysis and specific activity obtained for each of the four genotrophs after 1 and 24 hrs continuous labelling. The results (table 6) correlate well with those from table 5 indicating greater specific activity of total RNA in the $\mathrm{S}$ lines after $1 \mathrm{hr}$ but essentially no difference after $24 \mathrm{hrs}$.

TABLE 6

Specific activity of total RNA from flax roots. Seedlings were grown in the presence of $\left({ }^{32} \mathrm{P}\right)$-orthophosphate $(80 \mu \mathrm{Ci} / \mathrm{ml})$ for one hour or twenty-four hours

\begin{tabular}{|c|c|c|}
\hline Genotroph & $\begin{array}{c}1 \text { hour } \\
\text { RNA cpm } \mu \mathrm{g}^{-1}\end{array}$ & $\begin{array}{c}24 \text { hours } \\
\text { RNA cpm } \mu \mathrm{g}^{-1}\end{array}$ \\
\hline $\mathrm{L}_{0}$ & $\begin{array}{l}1605 \\
1492\end{array}$ & $\begin{array}{l}17,714 \\
18,305\end{array}$ \\
\hline$S_{0}$ & $\begin{array}{l}2052 \\
1800\end{array}$ & $\begin{array}{l}17,374 \\
21,647\end{array}$ \\
\hline $\mathrm{L}_{3}$ & $\begin{array}{l}1429 \\
2191\end{array}$ & $\begin{array}{l}27,066 \\
13,974\end{array}$ \\
\hline$S_{3}$ & $\begin{array}{l}2099 \\
2683\end{array}$ & $\begin{array}{l}18,739 \\
20,865\end{array}$ \\
\hline
\end{tabular}

\section{General discussion}

The aim of the work described above was to determine whether a two fold change in rRNA gene number brought about a parallel change in the product of these genes viz. rRNA. The methods used, whilst limited in their ability to detect subtle variations, are able to determine the presence of a two fold variation in rRNA transcription. Clearly quantitative variations in rRNA gene number in flax do not directly affect the amount of that gene's products in the cells. The multiple correlations also reported here, between various phenotypic characters related to plant vigour and size, may therefore be fortuitous. On the other hand rRNA accumulation rate is clearly greater in phenotypically large compared with small types and evidence indicates differences in control of rRNA and other genes. These controls however appear to be post-transcriptional and unrelated to the changes in rRNA gene number. 
Shermoen and Keifer (1975) showed that variation in rRNA accumulation in bobbed mutants of Drosophila melanogaster was correlated with macroscutellar bristle length but not with rDNA content. It seems likely that many rRNA genes are not transcriptionally active for various reasons including sequence heterochromatinization, the presence of intervening sequences and methylation of bases within the sequence (Givens and Phillips, 1976; Franz and Kung, 1981; Long and Dawid, 1979; Bird, 1978). A proportion of rRNA genes has been shown to be inactive in wheat (Flavell and O'Dell, 1979) and in maize (Givens and Phillips, 1976). However in wheat a general correlation was reported between rDNA amount and nucleolus size (Flavell and O'Dell, 1979). Although flax contains a low redundancy of genes for rRNA compared with most plants including wheat and maize, the number present is in considerable excess over the calculated requirements of its root tissues (Timmis et al., 1972).

A number of problems exist in the production of data on rRNA gene numbers. The determination of rRNA gene number relies heavily on estimates of DNA content per nucleus, usually by Feulgen photometry-a method which has known pitfalls (Bennett and Smith, 1976). Although the difference in nuclear DNA between $L$ and $S$ is highly significant and has been repeated by many workers in several different laboratories with considerable consistency (Evans et al., 1966; Durrant and Jones, 1971; Joarder et al., 1975; Durrant and Timmis, 1973; Cullis, 1976), the flax nucleus poses difficult problems for this sort of analysis. Indeed most of the cautionary details noted by Bennett and Smith (1976) apply to flax. The genome is very small, there are difficulties in staining the root tip tissues which is why shoot apices are normally used, and the nucleus is packed with heterochromatin. It is possible therefore that Feulgen measurements, whilst they undoubtedly reflect some difference between the $\mathrm{L}$ and $S$ nuclei, should be interpreted with more caution than has so far been accorded, as to their ability to estimate absolute DNA amounts. To add weight to this argument, the only non-Feulgen estimates of DNA in flax genotrophs do not show that $\mathrm{L}$ has more nuclear DNA than S. Using cytofluorometric stains, Schweizer (1980) obtained rather variable results which nevertheless indicated that $S$ nuclei bind more fluorescent dyes than $L$ nuclei in all eight comparisons made. Assuming this binding reflects DNA amount he showed that $S_{0}$ has a mean of 8.6 per cent more DNA per nucleus than $\mathrm{L}_{0}$-the reverse of Feulgen measurements. These results suggest that structural and organizational changes in the nuclei may be at least as important in generating apparent photometric differences as real quantitative changes. Estimates of the proportion of the flax genome complementary to rRNA are probably more unequivocal and are clearly greater in $\mathrm{L}_{0}$ than $\mathrm{S}_{0}$; in the present paper we give mean values of 0.454 per cent and 0.340 per cent respectively. Using the data of Schweizer (1980) as nuclear DNA values combined with the mean absolute value for flax (Bennett and Smith, 1976) we obtain rRNA gene numbers of 1830 for $L_{0}$ and 1500 for $S_{0}$. This very different rDNA estimate would completely alter the expectations for the present experiments, requiring a different approach to elucidating rRNA metabolism and rRNA gene utilization in flax. There is clearly a need to determine the presence or absence of quantitative DNA changes during induction in flax by methods other than microdensitometry. 
The experiments described here underline the difficulties of elucidating the relationship of molecular events in the genome with phenotypic characters in plants. The heterogeneity of plant tissues makes such experiments difficult to perform and to interpret. Yet material for testing the sort of control investigated here is not readily available in more well defined systems. The results clearly indicate the extreme caution necessary in using and interpreting data obtained from environmentally unstable lines of flax

Acknowledgement. - This work was supported by a grant from the National Board for Science and Technology of Ireland. We thank Mary Gavin for technical assistance and Sandra O'Connor for typing the manuscript.

\section{REFERENCES}

BENNETT, M. D., AND SMITH, J. B. 1976. Nuclear DNA amounts in angiosperms. Phil. Trans. Roy. Soc. London $B, 274,227-274$.

BIRD, A. P. 1978. Use of restriction enzymes to study eukaryotic DNA methylation: the symmetry of methylated sites supports semiconservative copying of the methylated pattern. J. Mol. Biol. 118, 49-60.

CULLIS, C. A. 1976. Environmentally induced changes in ribosomal RNA cistron number in flax. Heredity, 36, 73-79.

CULLIS, C. A. 1977. Molecular aspects of the environmental induction of heritable changes in flax. Heredity, 38, 129-154.

CULlis, C. A. 1979. Quantitative variation of rRNA genes in flax genotrophs. Heredity, 42 , 237-246.

DURRANT, A. 1958. Environmental conditioning of flax. Nature, 181, 928-929.

DURRANT, A. $1962 a$. The environmental induction of heritable changes in Linum. Heredity, $17,27-61$.

DURRANT, A. 1962b. Induction, reversion and epitrophism of flax genotrophs. Nature, 204, 1302-1304.

DURRANT, A. 1971. Induction of growth of flax genotrophs. Heredity, 27, 277-298.

DURRANT, A., AND JONES, T. W. A. 1971. Reversion of induced changes in amount of nuclear DNA in Linum. Heredity, 27, 431-439.

DURRANT, A., AND TIMMIS. J. N. 1973. Genetic control of environmentally induced changes in Linum. Heredity, 30, 369-379.

EVANS, G. M., DURRANT, A., AND REES, H. 1966. Associated nuclear changes in the induction of flax genotrophs. Nature, 212, 697-699.

FLAVELL, R. B., AND O'DELL, M. 1979. The genetic control of nucleolus formation in wheat. Chromosoma (Berl.), 71, 135-152.

FRANKHAM, R. 1977. Environmentally induced changes in rRNA cistron number: purported lack of correlation with phenotype. Heredity, 39, 175.

FRANZ, G., AND KUNZ, W. 1981. Intervening sequences in ribosomal RNA genes and bobbed phenotype in Drosophila hydei. Nature, 292, 638-640.

GIVENS, J. F., AND PHILLIPS, R. L. 1976. The nucleolus organizer region of maize (Zea mays L.). Ribosomal RNA gene distribution and nucleolar interactions. Chromosoma (Berl.), $57,103-117$.

HUMPHREYS, T. 1973. Quantitative measurement of RNA synthesis. In Chrispeeles, M. J. (ed.) Molecular techniques and approaches in developmental biology, Wiley \& Sons, pp. 141-163.

INGLE, J., TIMMIS, J. N., AND SINCLAIR, J. 1975. The relationship between satellite DNA, ribosomal RNA gene redundancy and genome size in plants. Plant Physiol., 55, 496-501.

JACKSON, M., AND INGLE, J. 1973. The interpretation of studies on rapidly labelled RNA in higher plants. Plant Physiol., 51, 412-414.

JOARDER, I. O., AL-SAHEAL, Y., BEGUM, J., AND DURRANT, A. 1975. Environments inducing changes in amount of DNA in flax. Heredity, 34, 247-253.

LONG, E. O., AND DAWID, I. B. 1979. Expression of ribosomal DNA insertions in Drosophila melanogaster. Cell, 18, 1185-1196.

PARISH, J. H. AND KIRBY, K. S. 1966. Reagents which reduce interactions between ribosomal RNA and rapidly labelled RNA from rat liver. Biochim. Biophys. Acta, 129, 554-562. 
RitossA, F. M., ATWOOD, K. C., AND SPIEgelmAN, S. 1966. A molecular explanation of the bobbed mutants of Drosophila as partial deficiencies of ribosomal DNA. Genetics, $54,819-834$

SCHWEIZER, D. 1980. Fluorescent chromosome banding in plants; applications, mechanisms, and implications for chromosome structure. In Davies, D. R., and Hopwood, D. A. (eds.) The Plant Genome, John Innes Charity, pp. 61-72.

SCOTT, N. S., AND INGLE, J. 1973. The genes for cytoplasmic ribosomal RNA in higher plants. Plant Physiol., 51, 677-684.

SHERMOEN, A. W., AND KIEFER, B. 1. 1975. Regulation in rDNA-deficient Drosophila melanogaster. Cell, 4, 275-280.

TIMMIS, J. N., AND INGLE. J. 1973. Environmentally induced changes in rRNA gene redundancy. Nature New Biol., 244, 235-236.

TIMMIS, J. N., AND INGLE, J. 1975a. The status of ribosomal RNA genes during nuclear DNA reversion in fiax. Biochem. Genetics., 13, 629-634.

TIMMIS, J. N., AND INGLE, J. 1975 b. Quantitative regulation of gene activity in plants. Plant Physiol., 56, 255-258.

TIMMIS, J. N., SINCLAIR, J., AND INGLE. J. 1972. Ribosomal RNA genes in euploids and aneuploids of hyacinth. Cell Differentiation, 1, 335-339.

WEINMANN, R. 1972. Regulation of rRNA and 5S RNA synthesis in Drosophila melanogaster bobbed mutants. Genetics, 72, 267-276. 